\title{
ACCELERATED STORAGE DEGRADATION TESTING AND FAILURE MECHANISMS OF AEROSPACE ELECTROMAGNETIC RELAY
}

\author{
BADANIA PRZYSPIESZONE DEGRADACJI W CZASIE SKŁADOWANIA \\ PRZEKAŹNIKÓW ELEKTROMAGNETYCZNYCH STOSOWANYCH \\ W PRZEMYŚLE LOTNICZYM ORAZ MECHANIZMÓW ICH USZKODZEŃ
}

\begin{abstract}
It is difficult to obtain the failure data of high-reliability and long-lifetime aerospace electromagnetic relay (EMR), even if based on the traditional accelerated storage life testing method. Based on the reliability test technique, the scheme of accelerated degradation testing for aerospace EMR was designed. The test system of aerospace electromagnetic relay storage parameters under temperature-accelerated stress was designed and developed. The most past research on storage reliability of relay only focuses on the measurement of contact resistance. The relay time parameters (pick-up time, opening time, overtravel time, rebound duration time, etc.) which reflect main performance function were not monitored. So, in this study the relay time parameters and relay contact resistance were detected simultaneously. According to the analysis on experiment results of contact resistance, relay time parameters, the degradation phenomena of aerospace EMR in long-term storage are investigated, which provides the bases for determining degradation sensitive parameters. Finally, based on the structure and function of aerospace EMR, the storage failure mechanism is investigated by conductive properties themselves. The microscopic morphology and changes in chemical elements for relay contact surface was analyzed by SEM and EDX regularly, which provide references for the relay storage failure mechanism.
\end{abstract}

Keywords: electrical contact; electromagnetic relay; failure mechanisms; storage reliability; degradation testing.

\begin{abstract}
Ze względu na wysoka niezawodność i dlugi cykl życia przekaźników elektromagnetycznych stosowanych w przemyśle lotniczym (EMR), trudno jest uzyskać dane o ich uszkodzeniach, nawet gdy korzysta się z tradycyjnej metody przyspieszonych badań dopuszczalnego okresu składowania. W przedstawionym artykule, opracowano, w oparciu o technikę badania niezawodności, schemat przyspieszonego badania degradacji przekaźników elektromagnetycznych stosowanych w lotnictwie. Zaprojektowano $i$ opracowano system oceny parametrów składowania przekaźników elektromagnetycznych używanych $w$ lotnictwie $w$ warunkach przyspieszonych przy skrajnych temperaturach. Ostatnie badania nad niezawodnościa składowania przekaźników koncentruja się wyłącznie na pomiarze rezystancji styku. Nie były w nich monitorowane parametry czasowe przekaźnika (czas załaczania, czas otwarcia, czas opóźnienia, czas trwania odbicia itp.), które odzwierciedlaja jego główne funkcje. W przedstawionych badaniach mierzono jednocześnie parametry czasowe przekaźników i rezystancję styków. W oparciu o analizę uzyskanych wyników doświadczeń, badano zjawiska degradacji EMR podczas ich dlugoterminowego składowania, co stanowiło podstawę do wyznaczenia parametrów wrażliwych na degradację. Wreszcie, w oparciu o strukturę i funkcje EMR, badano mechanizm powstawania uszkodzeń podczas ich składowania na podstawie właściwości przewodzacych. Prowadzone regularnie metodami SEM i EDX analizy budowy mikroskopowej oraz przemian pierwiastków chemicznych zachodzących na powierzchni styków przekaźnika stanowia odniesienie dla badań mechanizmu powstawania uszkodzeń podczas składowania przekaźników.
\end{abstract}

Stowa kluczowe: Styk elektryczny; przekaźnik elektromagnetyczny; mechanizmy uszkodzeń; niezawodność sktadowania; badania degradacji.

\section{Introduction}

Aerospace electromagnetic relay (EMR) is one kind EMR being required to have the higher technique level and reliablitiy. It has many advantages, such as larger ratio of breaking resistance to making resistance, higher contact power controlled by lower coil power, and simultaneous movement for multi-contacts. And it is one of indispensable electronic devices in the electronic systems of space flight.
They differ among themselves with a structure, purpose, and technical parameters [3]. Aerospace EMR is the key mechanical and electrical component in the national defence weapon system or industry to realize the functions of signal transmission, load switching, circuit protection and control, and system isolation.

The reliability of the relay research work can be summarized as reliability analysis, reliability design, and reliability testing. 
Professor Lu of Hebei University of Technology opened the relay reliability design precedent. A calculation model of product failure rate based on stress strength interference model provides the basis for the design of electromagnetic system [6]. Zhai studied the influence of the fluctuation of the parameters on the electromagnetic characteristics of the relay by orthogonal test [19]. Wang optimized the calculation method of dynamic characteristics of relay through FEM joint simulation and genetic algorithm, the calculation efficiency is improved, and was verified in actual production [20]. Li tested the contact resistance of the relay by pulse current method, and evaluated the relationship between the variation of contact resistance and contact reliability [4].

It is still in the exploratory stage. Reference [7] firstly tried to apply the accelerated life test to the study of the reliability of the relay, predicted the storage life and achieved preliminary results. But they only gave an exploratory test plan and had a certain exploration component for the selection of accelerated stress, the determination of test time and the selection of test stress level.

In the study of the accelerated life test scheme and simulation evaluation of the relay storage, $\mathrm{Li}$ aimed at optimal design of accelerated storage test scheme for relay small sample, they used the MCMC method based on Gibbs sampling and gave a Bayesian estimation method for the parameters of the relay accelerated life test model under the condition of multiple distribution. They presented a test method for evaluating the storage life of sealed relays according to the principle of step stress accelerated life test. In the censored cases, they set up the life distribution of Weibull distribution relay step stress accelerated life test model and used the likelihood method to calculate the life characteristics of the relay under normal stress level, but there is no experimental verification [5].

In the study of the failure mechanism and failure physics modeling, the related research has been carried out. Zang has studied the surface film of sealed relay and the film forming test has been designed. The pollution source which may lead to the increase of contact resistance has been analyzed [18]. According to the known relay failure mechanism, Wan tried to apply the PoF method to the prediction of the storage life of the relay, and the storage life was predicted by the time series method [16].

About the degradation test, Nair pointed out that degradation data is a rich source of information for reliability analysis in 1988 [15]. Reliability method based on product degradation data has become one of the important ways to solve the problem of high reliability and long life products. It is also an inevitable trend of the development of reliability evaluation methods from failure data to performance degradation data $[8,17]$. There has been a growing literature that is concerned with drawing reliability inferences from degradation data [10].

In view of the traditional reliability test method based on field storage reliability evaluation is very difficult to meet the storage requirements of long-life products, the test conditions, test method and test process of aerospace EMR storage degradation were studied in this paper. The contact resistance and time parameters of the relay are analyzed by using the graph analysis method, the variation law of relay performance parameters with time under storage conditions is obtained, on this basis, the contact resistance and the pick-up time are prescribed as sensitive parameters of storage degradation. Secondly, from the perspective of aerospace EMR function, structure and storage environment stress, the failure mechanism of the relay was analysed. SEM test and EDX analysis were used to analyze the microstructure and chemical composition of relay contacts periodically to provide the basis for analyzing the failure mechanism of relay storage.

\section{Accelerated degradation testing methods}

\subsection{Accelerated degradation testing}

Degradation is a physical or chemical process which causes the deterioration of the internal properties or states of the material under environmental stresses. The changing process will lead to product damage after a period of accumulation, which is represented by the changes of product parameters. The products will fail when the parameters reach certain order. One can accelerate the degradation by applying higher stresses (e.g., electrical stress, temperature stress, etc.) which is called accelerated stress [9]. The accelerated degradation test is an alternative to accelerated life testing which counts the time to failure. For the highly reliable and long-lifetime products that experience degradation of their performance, monitoring such degradation with time becomes a more efficient approach to estimate reliability than observing the actual failure time which might not occur during the test time $[11,12]$. Namely, accelerated degradation testing method is used when no failure or few failures are expected at normal testing conditions or even at accelerated life testing conditions.

A primary advantage of accelerated degradation test is that multiple degradation measurements can be recorded on each test processing. Compared to traditional accelerated life testing, this method yields plenty more reliability data. As a result, accelerated degradation testing method is suitable for high reliable products. From the standpoint of testing operability and product evaluation, the accelerated degradation sample should meet the following requirements. Firstly, performance degradation must be irreversible. Secondly, performance degradation can be accelerated. From the reliability pre-research test, accelerated storage testing based on parameter degradation for aerospace relay is feasible.

\subsection{Procedure of aerospace relay accelerated storage degra- dation testing (ASDT)}

Aerospace relay is one of the most important electromechanical components in weaponry equipments. The structural schematic of a certain aerospace relay is shown in figure 1 . This relay is a kind of common switch-type contact relay (one movable contact and two static contacts). The closing process was that when the coil was energized, the armature was moved by electromagnetic force, and the pusher arm pushed moveable spring moving until N.O. contact closed. The opening process was that when the electromagnetic system was power off, movable contact returned by mechanical spring force until N.C. contact closed.

The basic principle of constant stress accelerated degradation test is to separate the same batch of test items to different group, make acceleration test under a constant stress standard, there is a relationship between the product function degeneration and stress, function degeneration would be obviously increased under higher stress, then figure out the life of the products under normal stress from the performance degradation trace of accelerated degradation test.

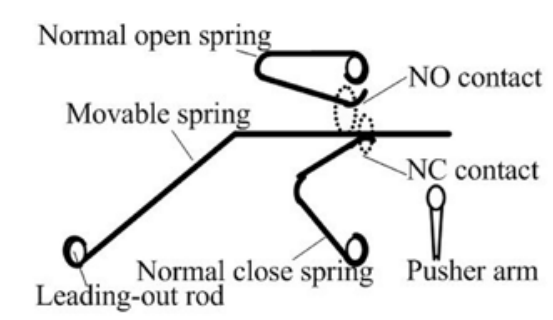

a) Contact system

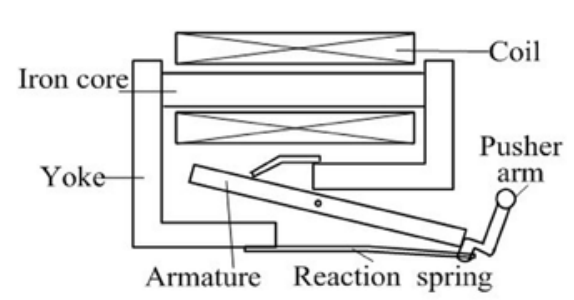

Armature Reaction spring

Fig. 1. Schematic structure of aerospace electromagnetic relay 
Aerospace relays are electromechanical elements that the structure is very complex. It will be influenced by many factors .In the period of storage, its failure mechanism is complex. It is better to put multiple stresses than to put single environmental stress, multiple stresses may reflect the real environment, show more limitation of the product. But we must realize that to put multiple stresses will make the experiment more difficult, even bring more interference. These limitations maybe lead to some unexpected results: the data get from experiment may not be dealt. Reference [6] pointed out that the temperature factor is the main influencing factor causing relay failure. Temperature will accelerate physical and chemical process of relay, thus accelerated failure time. So this paper selects the temperature as main accelerated stress, and studies the storage reliability of aerospace relay using the method of constant stress accelerated storage degradation test. The characteristics of storage test are time-consuming, slow degradation. 40 relays were divided into four groups on average and put them in 4 temperature test chambers. The performance degradation parameters are tested and analyzed regularly.

The performance degradation parameters should be able to reflect the aerospace relay storage life, the changes of reliability and have clear physical meanings; in addition they should be measured easily. The performance degradation parameters should have obvious degradation trend, as the accelerated storage life test went on. In order to gain the contact reliability information and contact states as much as possible in contacts storage test, aside from contact resistance this paper also test and analysis time parameters: pick-up time, opening time, overtravel time, and rebound duration time.

Considering the accelerated ability of performance and reliability pre-research test, we determine the lowest stress and highest stress were $80^{\circ} \mathrm{C}$ and $170^{\circ} \mathrm{C}$. In order to make the middle stresses scattered as far as possible, and the middle stresses were chosen as follows:

$$
\Delta=\frac{1}{T_{1}}-\frac{1}{T_{2}}=\cdots=\frac{1}{T_{k-1}}-\frac{1}{T_{k}}=\left(\frac{1}{T_{1}}-\frac{1}{T_{k}}\right) /(k-1)
$$

When $k=4$, therefore, one can get the middle stress are $106^{\circ} \mathrm{C}$ and $135^{\circ} \mathrm{C}$. The test conditions are as tabled 1 .

Table 1. Test conditions of relay accelerated storage degradation test

\begin{tabular}{||l|l||}
\hline \hline Temperature stress & $80^{\circ} \mathrm{C}, 106^{\circ} \mathrm{C}, 135^{\circ} \mathrm{C}, 170^{\circ} \mathrm{C}$ \\
\hline Number of samples & 10 relays / temperature \\
\hline Test frequency & 2 days \\
\hline Current & $10 \mathrm{~mA}$ \\
\hline parameters test condition & $\begin{array}{l}\text { Samples were cooled to room tem- } \\
\text { perature in } 2 \text { hours until testing. }\end{array}$ \\
\hline
\end{tabular}

The physical map and major structures of the relay ASDT test system are shown in figure 2.This system can monitor relay contact resistances and time parameters of 40 aerospace relays by turns under different temperatures and transmit the test data to the host computer for processing.

\section{Results and discussion of aerospace relay accelerated storage degradation testing}

\subsection{Analysis of storage test results of relay contact resist- ance}

The contact resistance is an important indicator to measure the relay performance. The variations of the average contact resistance of total 40 relays under 4 temperature-accelerated stresses are shown in figure 3 , during near 1 year accelerated storage testing process.

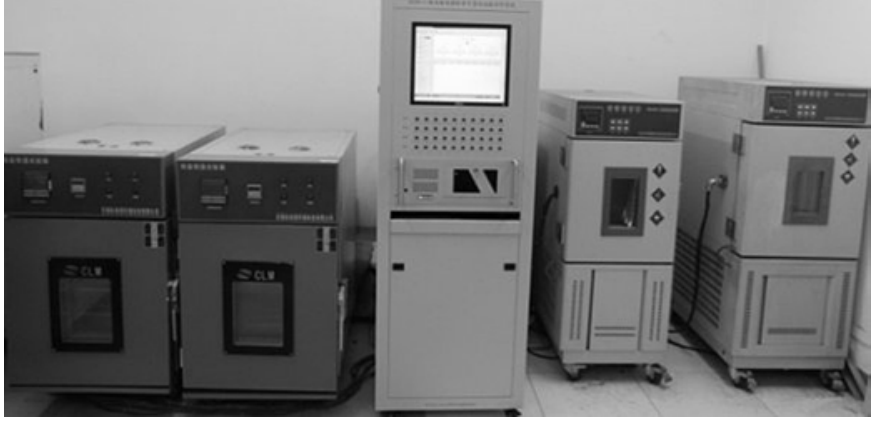

a) Physical map of relay testing system

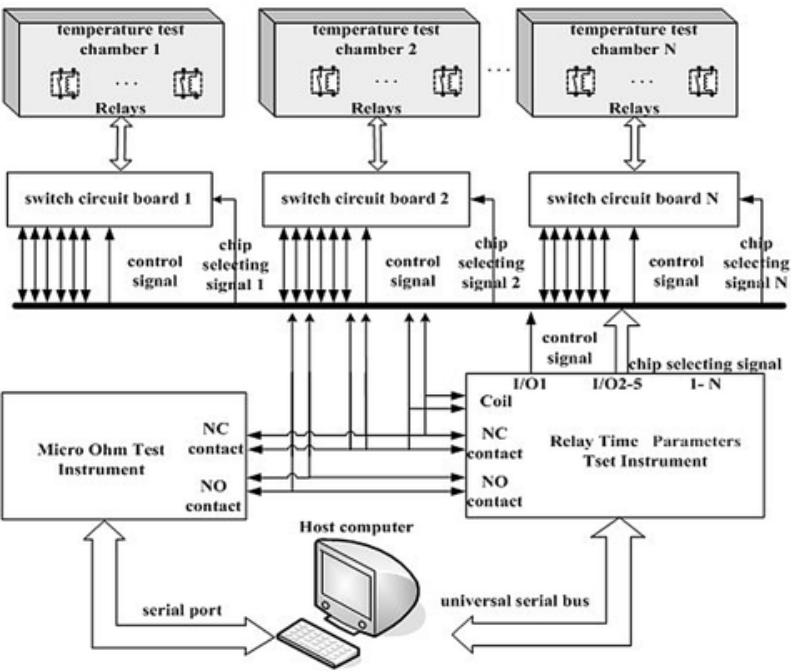

b) Major structures of relay testing system

Fig. 2. Physical map and major structures of relay ASDT test system

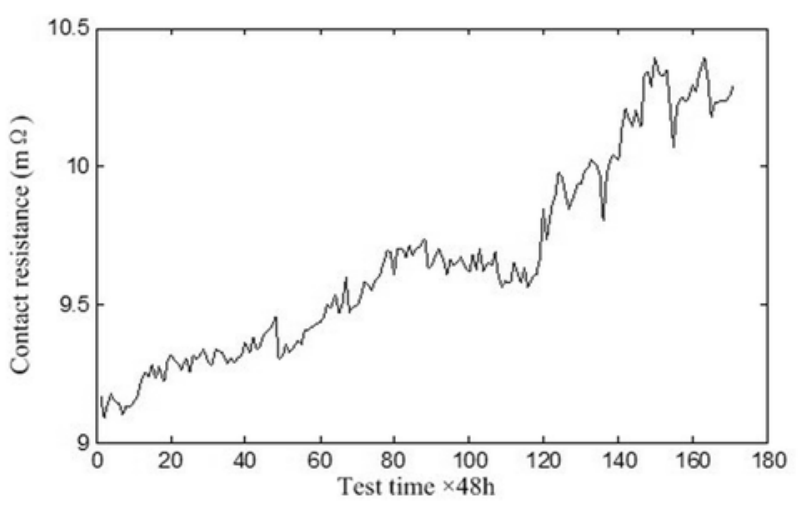

a) $80^{\circ} \mathrm{C}$ storage test condition

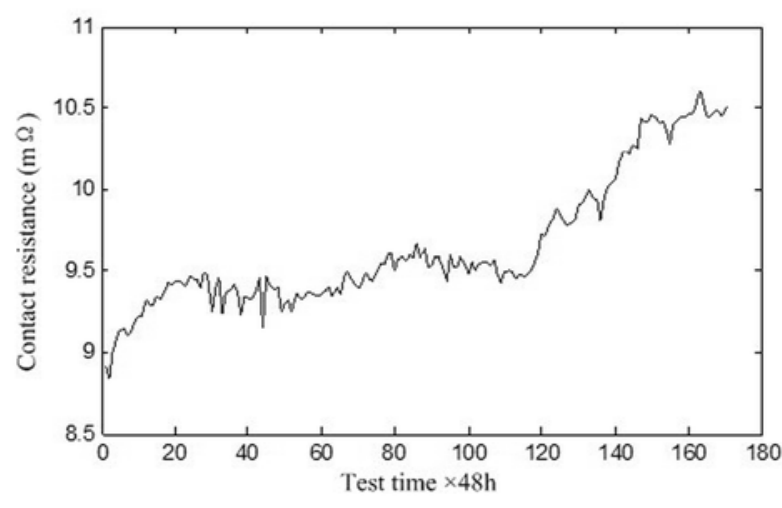

b) $106^{\circ} \mathrm{C}$ storage test condition

Fig. 3. Scatter plots of average contact resistances for different temperatures 


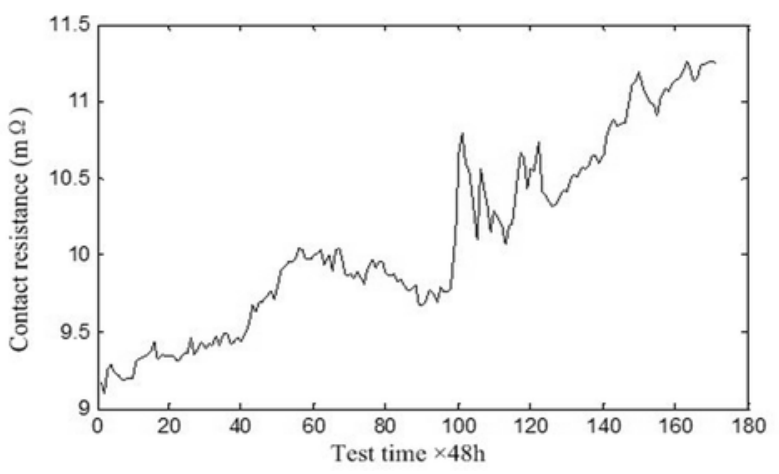

c) $135^{\circ} \mathrm{C}$ storage test condition

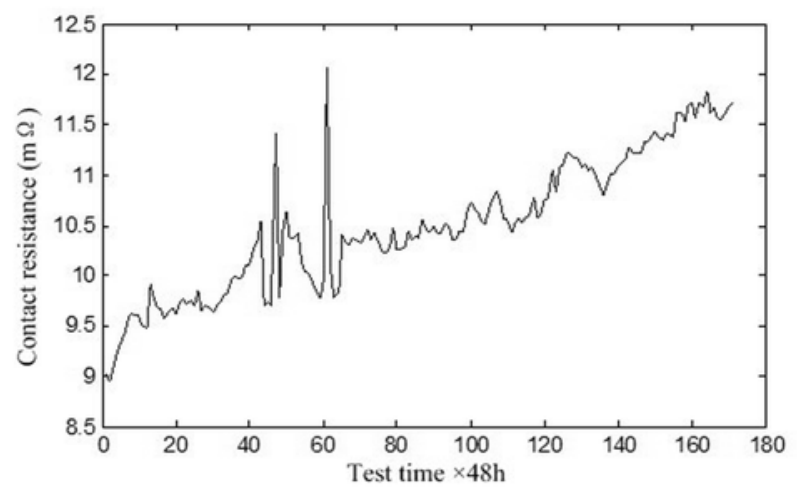

d) $170^{\circ} \mathrm{C}$ storage test condition

Fig.3. Scatter plots of average contact resistances for different temperatures

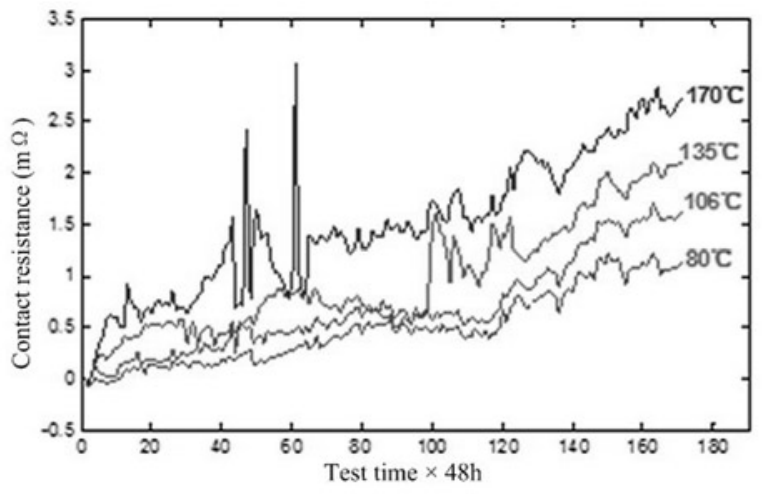

Fig. 4. Scatter plots of average degradation contact resistances with different temperatures

The degradation measures of relay contact resistance under 4 temperature-accelerated stresses in accelerated storage degradation testing are shown in figure 4.

From Figure 3 and Figure 4, it is not difficult to find that in the period the contact resistance is mostly concentrated in $9 \mathrm{~m} \Omega \sim 12 \mathrm{~m} \Omega$. Contact resistance is increasing at each temperature. The temperature promotes the degradation of contact resistance. When the temperature-accelerated stress is higher, the rate of contact resistance growth is faster, and the value is also greater.

The variation of contact resistance reflects the cumulative degradation of the contact during relay's accelerated storage period to some extent. The surface of contact will appear the surface oxide film growth and accumulation as the storage time prolongs, the corrosion growth directly reflects the degradation of the relay contact. The contact material of test aerospace relay is Ag-based coated with a thin layer of gold. The gold plating is very thin which is about $1.8 \mu \mathrm{m}$.

\subsection{Analysis of storage test results of relay time parameters}

The relay time parameters are described in figure 5 and specific defined as follows:

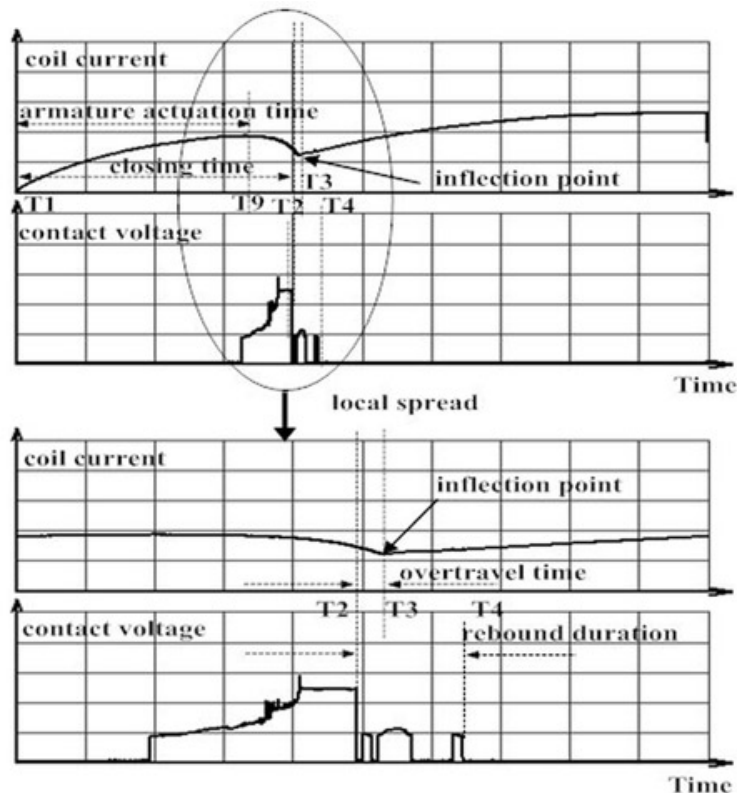

T1 - Coil energization, T2 - Movable contact and N.O. contact first contact, T3 - Armature closed T4 - Contact rebound finished, T9 - Armature actuation a) Closing process

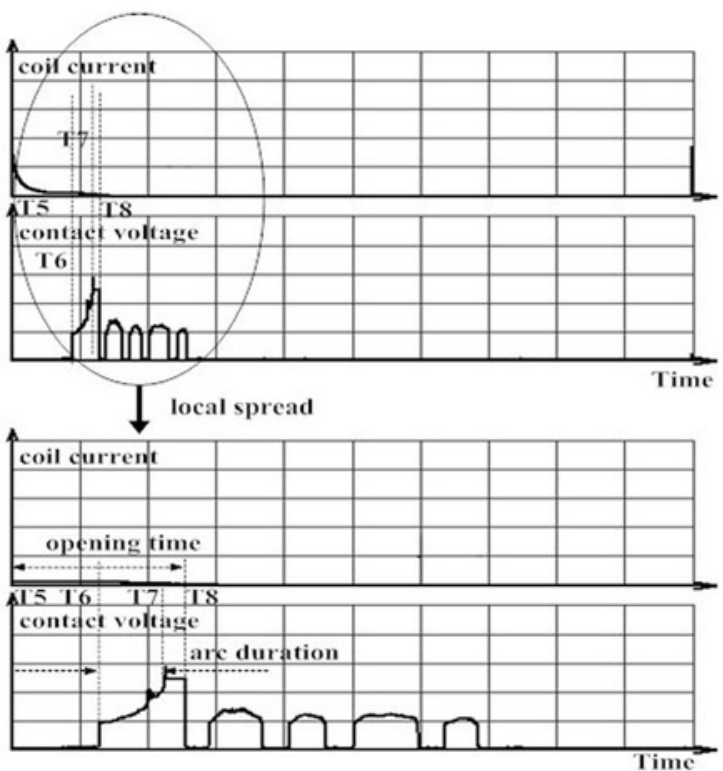

T5 - Coil power off, T6 - Movable contact and N.O. contact part from each other, $\boldsymbol{T} 7$ - Movable contact and N.O. contact completely separated, $\boldsymbol{T} \boldsymbol{8}$ - Movable contact and N.C. contact first contact b) Opening process

Fig. 5. Oscillograms of coil current and contact voltage during the closing and opening process

- Pick-up time: the time from the power-on of electromagnetic system to the first contact of movable contact and N.O. contact. (T2-T1)

- Opening time: the time from the power-off of electromagnetic system to the first contact of movable contacts and N.C. contact. (T8-T5)

- Overtravel time: the time from the first contact of movable contacts and N.O. contact to full pick-up of the armature. (T3-T2) 
- Rebound duration time: the time from the first contact of movable contacts and N.C. contact to the end of rebound during the pick-up period. (T4-T2)

\subsubsection{Test results of pick-up time}

Pick-up time is the time from the power-on of electromagnetic system to the first contact of movable contact and N.O. contact. With

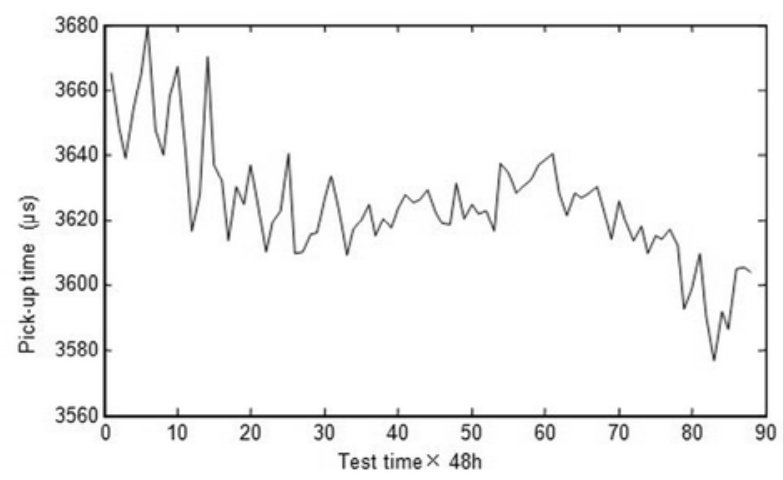

a) $80^{\circ} \mathrm{C}$ storage test condition

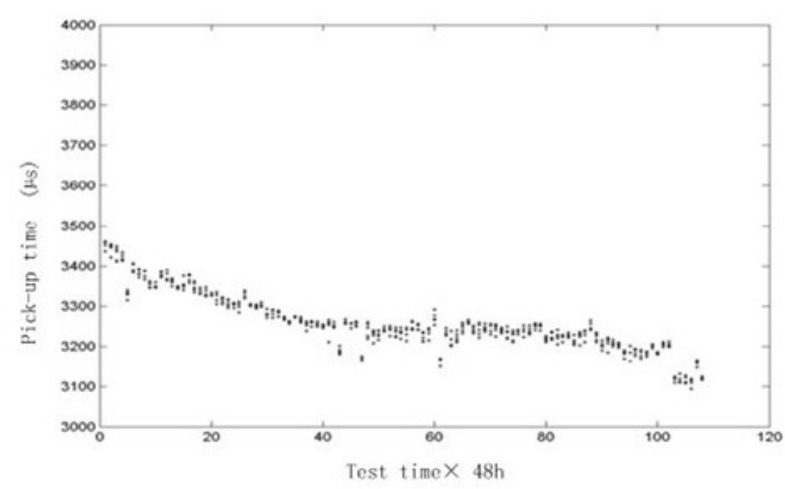

b) $106^{\circ} \mathrm{C}$ storage test condition

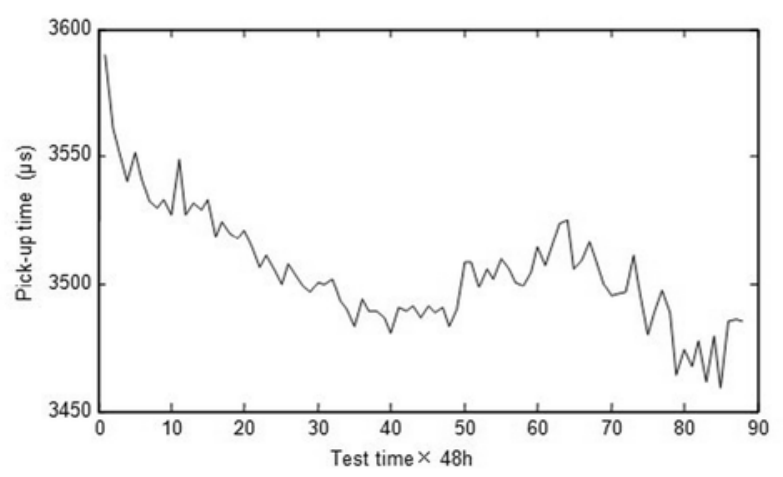

c) $135^{\circ} \mathrm{C}$ storage test condition

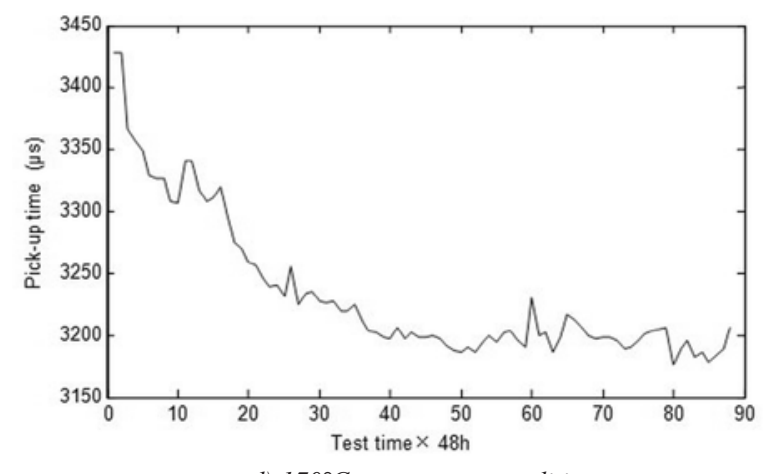

d) $170^{\circ} \mathrm{C}$ storage test condition above test system, the relay pick-up time data were obtained by storage accelerated test on 40 relays over 180 days under 4 temperatureaccelerated stresses, and the average value of relay pick-up time is shown in figure 6 . The degradation measures of pick-up time at 4 temperature-accelerated stresses in accelerated storage degradation testing are shown in figure 7.

It is shown that the pick-up time is on a declining trend under high temperature long term storage. The curve has two steps decrease obviously. The first step declines faster and the second step declines slowly. The most decrease of pick-up time appears on the first step.

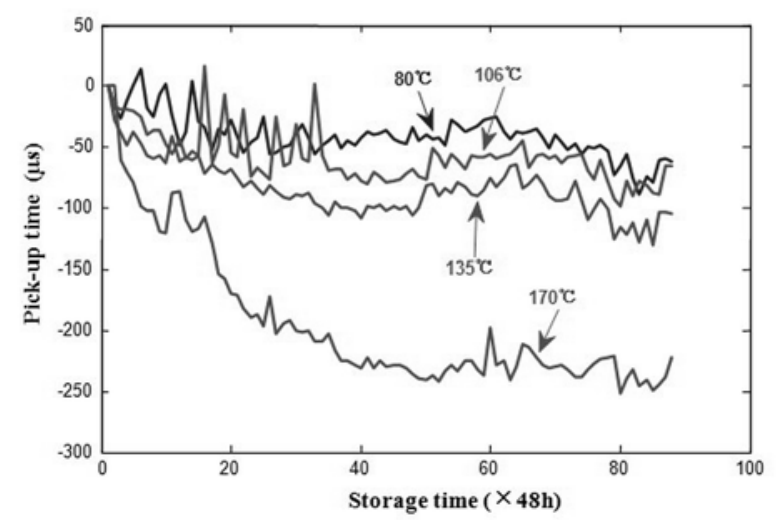

Fig. 7. Scatter plots of average degradation pick-up time with different temperatures

Pick-up time generally including armature actuation time, break time, free travel time, and all of the change of these components will have impact on it.

In figure 5-a), from the oscillograms of coil current during the closing process, we can see T9 is armature actuation time which occupies much time in pick-up time. The relay armature actuation time is mainly influenced by electromagnetic force, reaction force and contact travel. By measuring the coil resistances before and after the test, we found the value of coli resistance has very small change. So, it indicated that the electromagnetic force is basically unchanged. The corrosion film appears between contacts is very thin and can be neglected, we assume contact travel constant. Hence, pick-up time is merely about reaction force. The stress of reaction spring's bending angle may release and thus cause reaction spring pre-pressure decreases during accelerated storage test. This makes armature actuation time decrease, so it has mainly impact on the pick-up time. Of course, there may be some exceptions. Such as N.C. contact may appear cold viscosity during the test, which will lead to the longer armature actuation time.

\subsubsection{Test results of opening time}

Opening time is the time from the power-off of electromagnetic system to the first contact of movable contacts and N.C. contact. During the release process, only the reaction force spring acts on the armature. Opening time includes initial release time, N.O. contact break time and free travel time.

The opening time is generally related to the contact gap, the contact surface structure and the spring rate. Figure 8 shows the box-andwhisker plots of opening time with different temperatures.

The fluctuation range of opening time curve was higher, and the degradation trend was not obvious. There are a number of outliers in opening time data. After wiping off the abnormity data, there is a little fluctuation in the median of a data set, which means that the opening time would either be not a storage degradation sensitive parameter over time.

Fig. 6. Scatter plots of relay pick-up time with different temperatures 


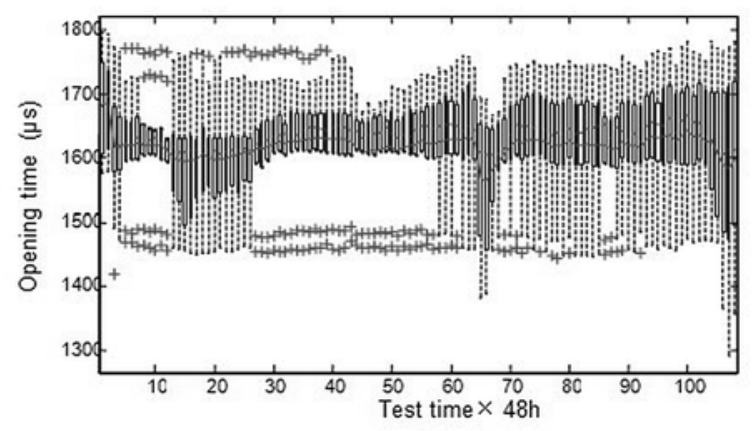

a) $80^{\circ} \mathrm{C}$ storage test condition

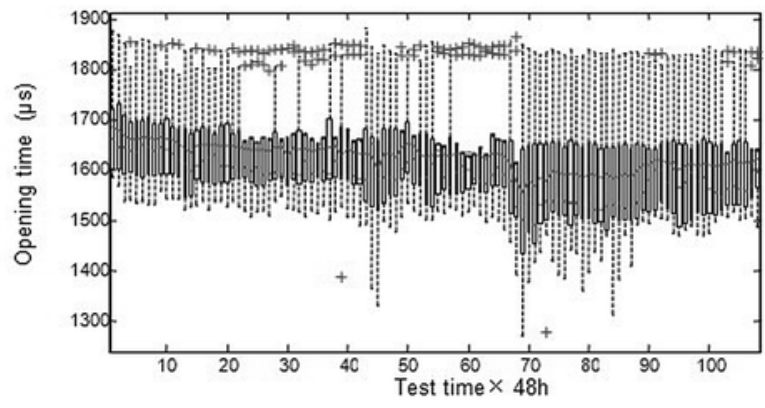

b) $106^{\circ} \mathrm{C}$ storage test condition

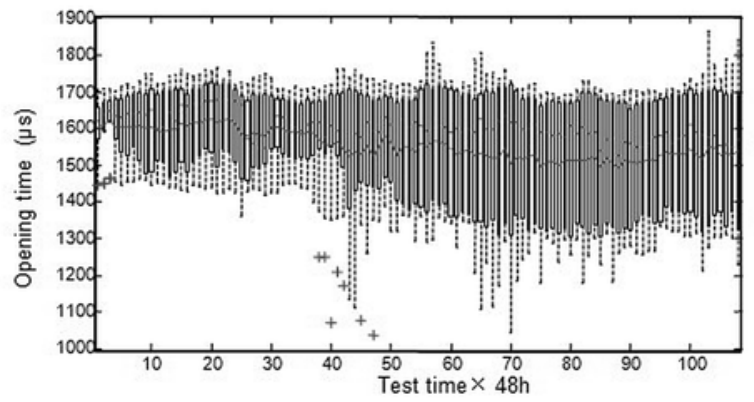

c) $135^{\circ} \mathrm{C}$ storage test condition

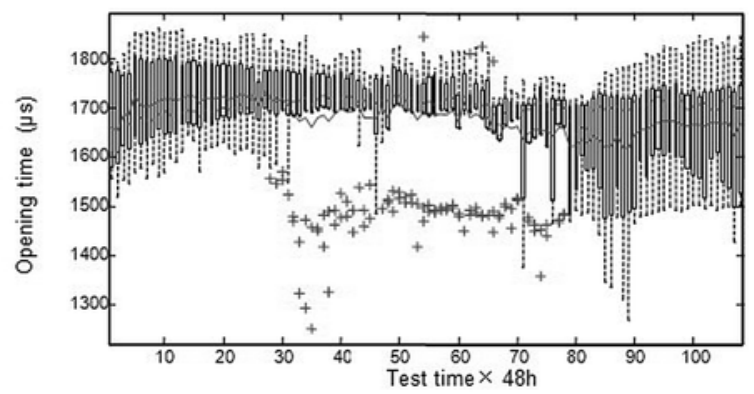

d) $170^{\circ} \mathrm{C}$ storage test condition

Fig. 8. Box-and-whisker plots of opening time with different temperatures

\subsubsection{Test results of overtravel time}

The relay overtravel time data were obtained by storage accelerated test on 40 relays over 180 days under 4 temperature-accelerated stresses, and the Box-and-whisker plots of relay overtravel time is shown in figure 9.

The fluctuation range of overtravel time curve was higher, and the degradation trend was not obvious. There are a number of outliers in overtravel time data. After wiping off the abnormity data, there is a little fluctuation in the median of a data set, which means that the

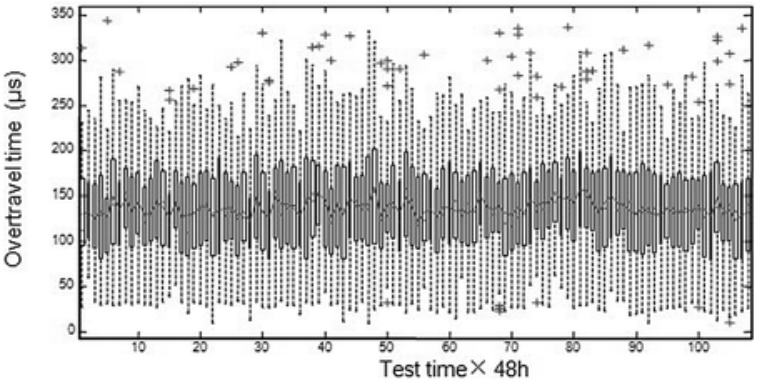

a) $80^{\circ} \mathrm{C}$ storage test condition

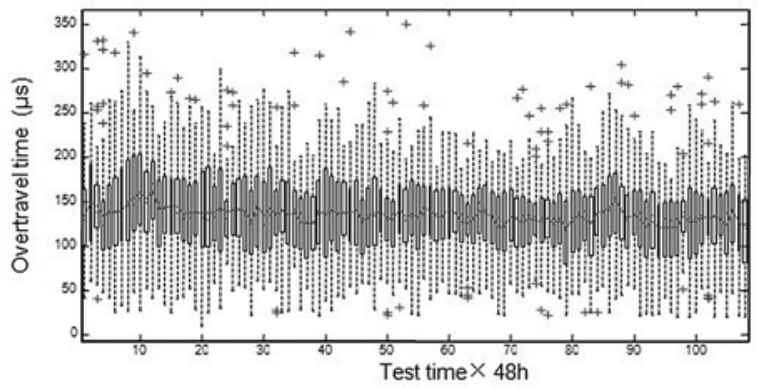

b) $106^{\circ} \mathrm{C}$ storage test condition

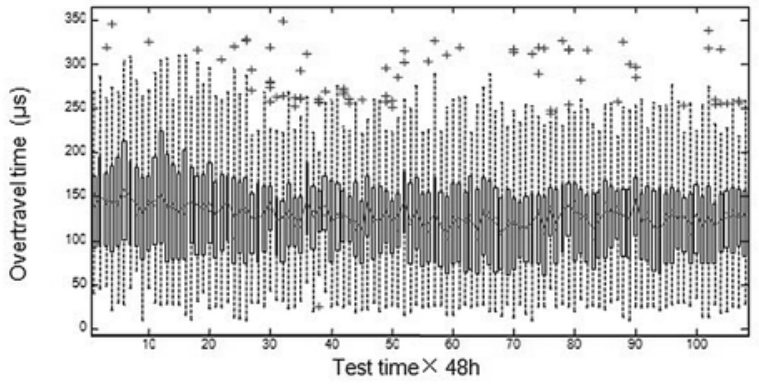

c) $135^{\circ} \mathrm{C}$ storage test condition

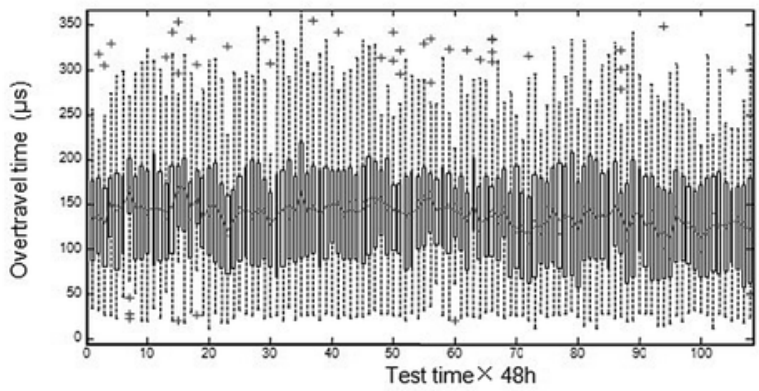

d) $170^{\circ} \mathrm{C}$ storage test condition

Fig. 9. Box-and-whisker plots of overtravel time with different temperatures

overtravel time would either be not a storage degradation sensitive parameter over time.

\subsubsection{Test results of rebound duration time}

The relay rebound duration time data were obtained by storage accelerated test on 40 relays over 180 days under 4 temperature-accelerated stresses, and the scatter diagram of relay rebound duration time is shown in figure 10.

The fluctuation range of rebound duration time curve was higher, and the degradation trend was not obvious. There are a number of outliers in overtravel time data. There is great randomicity and uncertainty of the trend in the overtravel time test data, which means that 


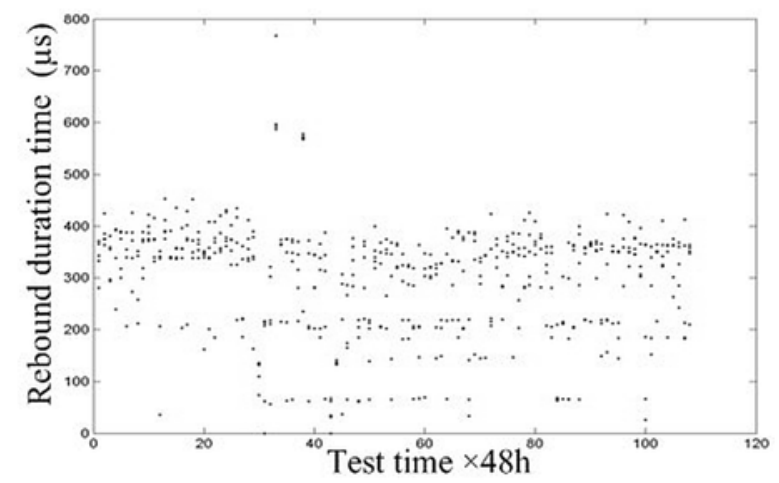

a) $80^{\circ} \mathrm{C}$ storage test condition

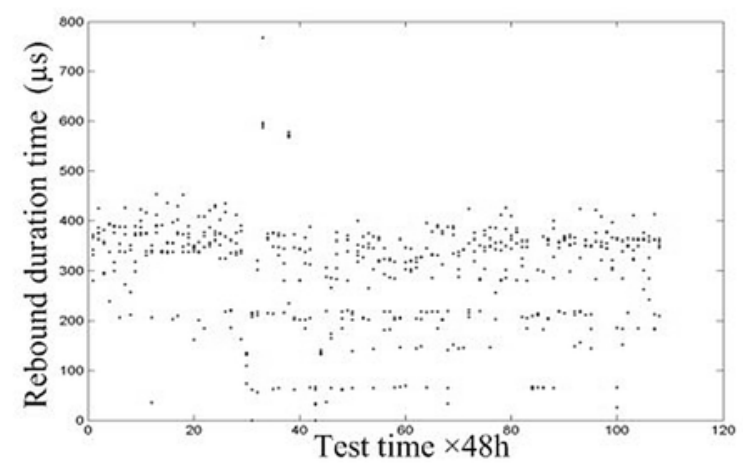

b) $106^{\circ} \mathrm{C}$ storage test condition

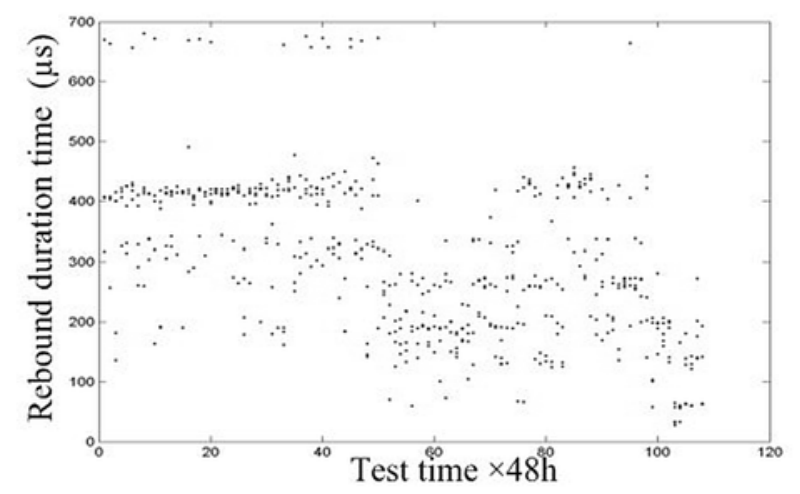

c) $135^{\circ} \mathrm{C}$ storage test condition

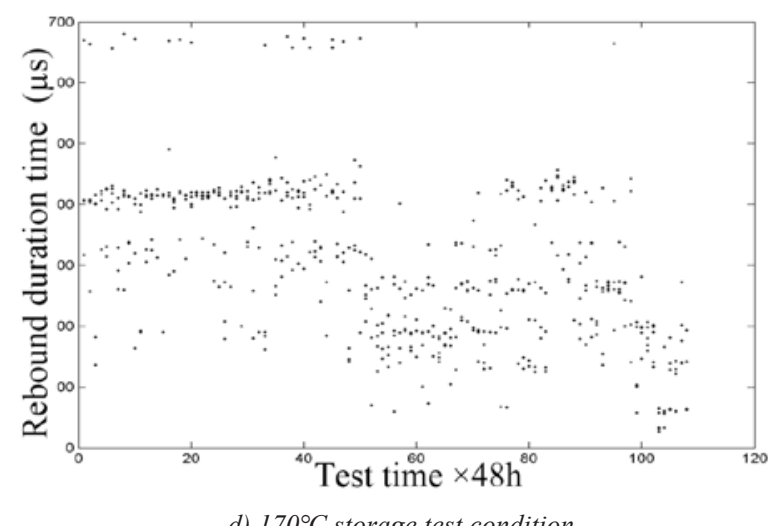

Fig. 10. Scatter plots of average rebound duration time

the overtravel time would either be not a storage degradation sensitive parameter over time.

\subsection{Determination of storage degradation sensitive param- eters}

From the standpoint of testing operability and product evaluation, to determine the degradation sensitive parameters should note the following points. Firstly, performance degradation must be irreversible. Secondly, performance degradation could be accelerated.

From the analysis of storage test results, when the temperatureaccelerated stress is higher, the rate of contact resistance growth is faster, and the value is also greater. When the temperature-accelerated stress is higher, the trend of pick-up time values descend is obvious, and the value is also smaller. The relay contact resistance and pick-up time satisfy two characteristics described in determination degradation sensitive parameters. But, the relay opening time, overtravel time and rebound duration time do not meet the conditions of sensitive parameter's definition.

Finally, the sensitivity parameters such as relay contact resistance as well as pick-up time were determined in accelerated storage degradation testing.

\section{Storage failure mechanism analysis of aerospace EMR}

\subsection{Contact conductive properties of relay}

The touching component of aerospace EMR usually consists of silver alloy or copper alloy with a layer of gold of a few microns. The metal surface may be very smooth with the naked eye. However, at the perspective of microscopic, actually is mat and jagged[2].When two metal surface have touch with each other, the really contact only occurs in a few salient points and a part of conducting spots can have the ability of conducting electricity.

In other words, the electrical contact with two solids forms in the some areas among touching surface, the only path of conducting current, as shown in figure 11. When current flows past touching surface and pass through those conducting spots, the current lines begin to constriction resulting resistance values increase correspondingly, which is called constriction resistance[1], expressed as $R_{S}$. Because conducting surface among touching surface may be not clear totally, the influences from oxide film, water film, sulfide film, dust or other inorganic membranes change potential distribution of current path and have a influence of distribution of electronics, resulting in the increasing of the other extra resistance, called membrane resistance, the other component constituting contact resistance, expressed as $R_{f}$.According to Holm electrical contacting theory, total contact resistance equal to the series resistance of constriction resistance, film resistance and some parts of volume resistances [2]:

$$
R=R_{s}+R_{f}+R_{v}==\frac{\mathrm{r}}{2 n a}+\frac{\sigma}{\mathrm{p} n a^{2}}+R_{v}
$$

Formulas $\rho-$ The contacts average resistivity;

$\sigma$ - Film tunnel resistivity;

$n$ - The number of the contact spots;

$a$ - The radius of the conductive spots;

$R_{v}$ - Volume resistance.

So, the physical meaning of contact resistance is the sum of an increase in resistance of the metal (constriction resistance) caused by shrinkage effect created by current among conducting spot between contacts, the surface film resistance and body resistance. However, the combined effects for the radius of conducting spot and resistivity, created by the chemical stability of the contact material, the roughness of the contact spot in contact surface, contact pressure and environmental factors outside (temperature, humidity, atmosphere, etc.),lead 

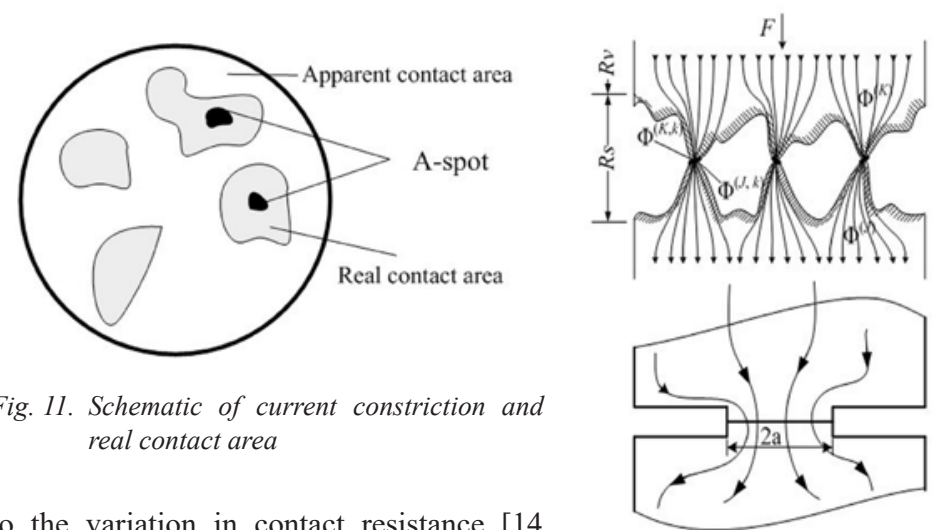

to the variation in contact resistance [14, 13].

\subsection{Contacts failure mechanism analysis of aerospace EMR}

\section{a : A-spot radius}

$R_{\mathrm{m}}$ : Conductor resistance

$R v$. Volume resistance

Among the structure of aerospace EMR, the contact system is the core part of the relay in the long-term storage. In order to have good conductivity, it is necessary to ensure a stable contact between contacts and contact interfaces; otherwise it may cause the relay contact failure.

According to statistical analysis of historical data based on natural storage of relay manufacturer, during long storage failure, the contacts failure accounted for $62.8 \%$ of the total failure .It is the main failure mode, the main form of which is the barrier between contacts and the variation in contact resistance.

Storage reliability of aerospace EMR has a close relation with change of the contact resistance among the relay contacts. Under storage conditions the growth rate of the contact resistance among contacts has a close relation with the growth rate of the corrosion products among contacts. Reference [18] studied the surface film of sealed relay contacts, pointed that contact surfaces of aerospace relay have $\mathrm{Ag}, \mathrm{Au}, \mathrm{O}, \mathrm{S}, \mathrm{Cl}$ and other elements and analyzed that rosin flux, vacuum plastic, etc. have a great influence on the growth of surface film in contacts.

In this study, the material of contacts in aerospace EMR is gold-plated silver-based alloy and gold plating layer is generally thin $(1.8-3.2 \mu \mathrm{m})$. During the gold-plated contacts process, because the process and other reasons, it will inevitably appear some mechanical scratches, abrasions, micro-cracks, holes or other impurities in the coating, as shown in figure 13.

During the long storage of aerospace electromagnetic relay, the sealing will continue to decline over time, so that atmospheric oxygen and corrosive gases will continue to enter the interior of the housing of the relay, and through the capillary action of cracks and pores [21], penetrate and come into contact with the base metal silver of contacts and deposited to form an electrolyte. The potential difference between the metallic silver and gold so that it forms original battery at the interface of the base metal silver and the coating metal, resulting electronic flows, which occurred a redox reaction, as shown in the following formula:

$$
\mathrm{Ag} \rightarrow \mathrm{Ag}^{+}+\mathrm{e}^{-}
$$

Because the oxide growth rate of silver is dependent on its lattice disturbed state, and chemical activity of $\mathrm{Ag}^{+}$is strong, its diffusion rate in the solid oxide is much faster than the diffusion rate of oxygen, so its diffusion to the oxide-gas surface is much easier, in other words, the diffusion rate of $\mathrm{Ag}^{+}$from interface of $\mathrm{Au}-\mathrm{Ag}$ to the surface of coating much faster than $\mathrm{H}_{2} \mathrm{O}$ and. $\mathrm{O}_{2}$, when the atmosphere contains trace corrosive gases, such as $\mathrm{SO}_{2}$ or $\mathrm{H}_{2} \mathrm{~S}$, then the reduction reaction of the electrochemical reaction takes place on the surface of the gold layer, that is also called the contact surface, and form a high resistivity layer of dark black corrosion film on the contact surface. The chemical reaction is as follows:

$$
4 \mathrm{Ag}^{+}+\mathrm{O}_{2}+2 \mathrm{H}_{2} \mathrm{~S} \rightarrow 2 \mathrm{Ag}_{2} \mathrm{~S}+2 \mathrm{H}_{2} \mathrm{O}
$$

The main component of the formative layer is sulfide and oxide of silver. Both sulfide atmosphere and friction of contact action will promote the formation of sulfides and oxides. $\mathrm{Ag}_{2} \mathrm{~S}$ has high resistivity, which is about ten thousand times of $\mathrm{Cu}$, the resistivity at room temperature is between $10^{7}-10^{18} \Omega \cdot \mathrm{mm}$, so the impact on contact resistance is great. The hardness of silver sulfide the oxide is much lower than metal silver, the shear strength is small, therefore it can be easily broken, corrosion film loose. Since redox reaction on the contact surface continues, reactants piled up, such that corrosion film will continue thickening, resulting in increased contact resistance between the contacts, finally resulting in contact failure. Fig. 12 is a comparative morphology of EMR make static contacts for a longterm before and after corrosion.

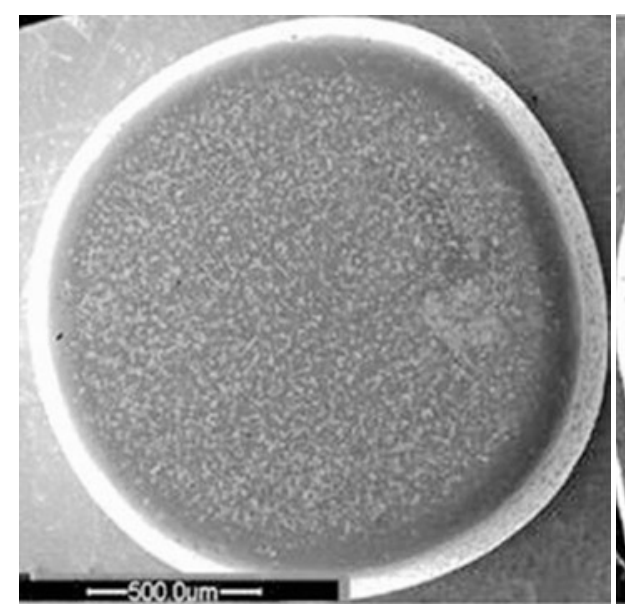

a) Initial state of N.C. contact

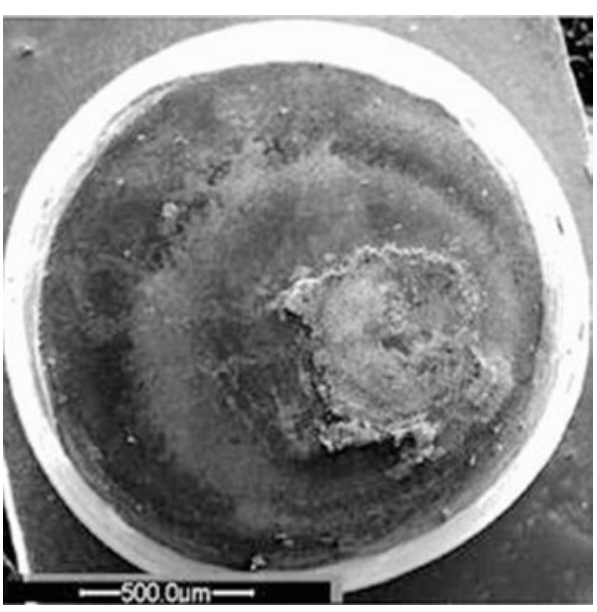

b) N.C.contact morphology after corrosion
Fig. 12. N.C.static contact morphology of electromagnetic

According to the theory of Holm electrical contacts, due to the tunnel effect, increased in the film thickness of the oxides and sulfides can result in increased resistivity of the tunnel, leading to increase in contact resistance, which destroys the electrical contact properties of the gold layer, causing performance of relay contacts declining, such changes caused by environmental factors of contact materials is irreversible, and it is irrecoverable process. When the film thickness is less than $3 \mathrm{~nm}$, the increasing thickness $L$ and the tunnel film resistivity $\sigma$ are substantially linear.

$$
\sigma=\eta L
$$

Formulas $\eta$-scale factor. 
Because the membrane resistance can be expressed as $R_{f}=\sigma / \mathrm{A}$, incremental of contact resistance with time can be expressed as the following formula:

$$
R_{t}=\eta\left(L-L_{0}\right) / \mathrm{A}
$$

Formulas $L_{0}$ - the original film thickness;

$A$-Actual contact area of the conductive spots.

It is obviously, in long-term storage environment, aerospace EMR contacts degradation in performance is mainly due to the accumulation of oxides and sulfides generated on the surface, therefore, the growth rate of corrosion products on contact surfaces can be used to evaluate the indirect contact performance of degradation processes.

\subsection{Analysis of contact morphology and chemical constitution}

In order to further reveal the degradation of long storage of the relay and analyze its storage degradation mechanism, we can use Scanning Electron Microscope (SEM) and Energy Dispersive X-Ray Spectrometer (EDX) to observe the EMR contacts of storage test, observe the changes of surface morphology and chemical changes of the contact surface.

\subsubsection{SEM test of relay contacts}

Figure 13 shows the static contacts and changeover contact of new aerospace EMR samples with $50 \times$ SEM morphology photograph .

From the figure 12, we can see although it is a new aerospace electromagnetic relay samples, but the contact surface is not completely smooth, there are varying degrees of micro mechanical wear or scratches. These wear scratches are mainly due to the relay assembly process. In the debugging process of structural parameters, many steps require manual debugging, and some mechanical friction is inevitable. The contact area of the wear scratches will damage the contact surface of the gold coating, make the oxygen and other corrosive gases are subjected to oxidation reduction with contact base metal silver by micro capillary action, so that affecting the performance of contacts. During the long storage the relay contact oxidation corrosion more serious parts also occurred in the parts of the mechanical wear.

Figure 14 is the SEM surface morphology of the static contacts in different temperatures in a storage test which lasts nearly a year. From this analysis of SEM morphology of figure 14, it is not difficult to find that as the temperature rises, the relay surface oxidized corrosion severity also increases, and most of them occurs in the wear at the contact surfaces. Moreover, these relay surface oxidized corrosion always

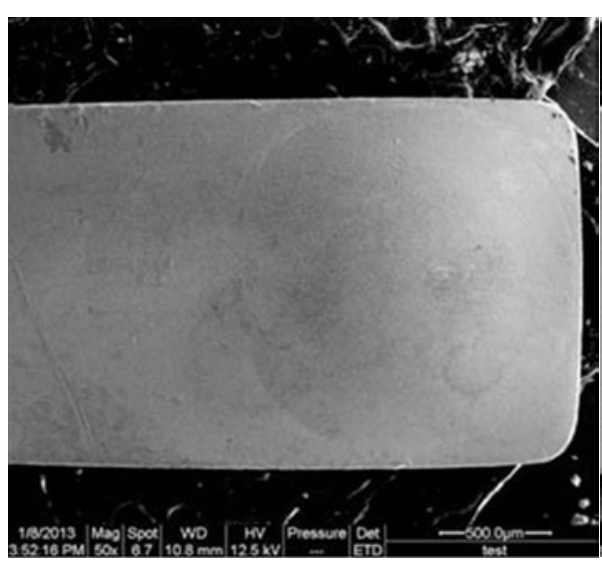

a) $80^{\circ} \mathrm{C}$ storage test condition

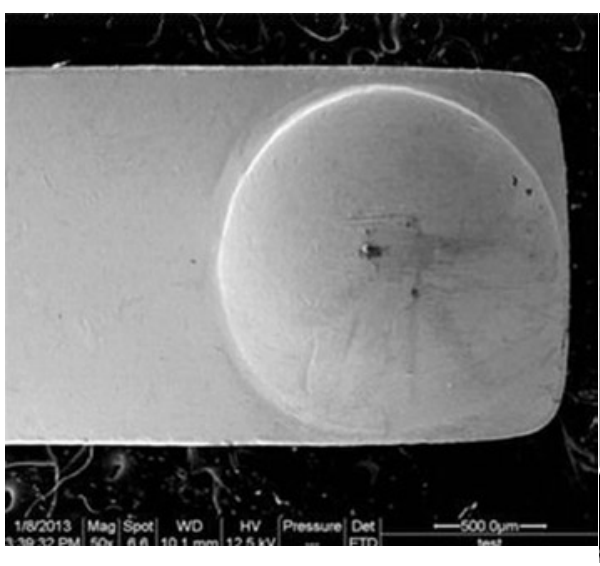

c) $135^{\circ} \mathrm{C}$ storage test condition

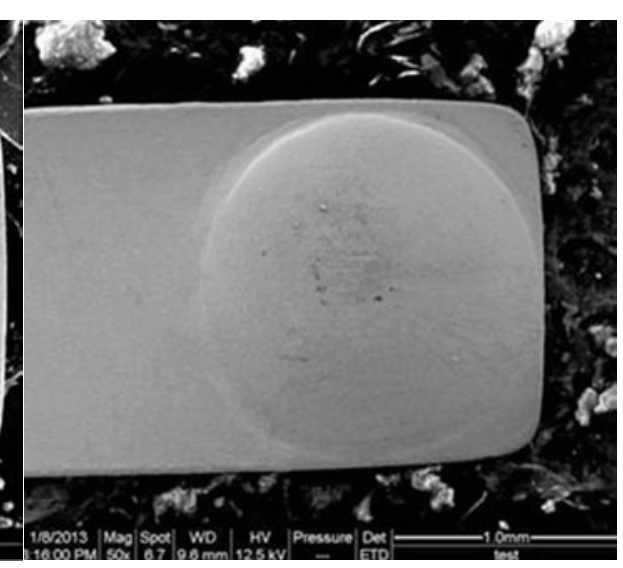

b) $106^{\circ} \mathrm{C}$ storage test condition

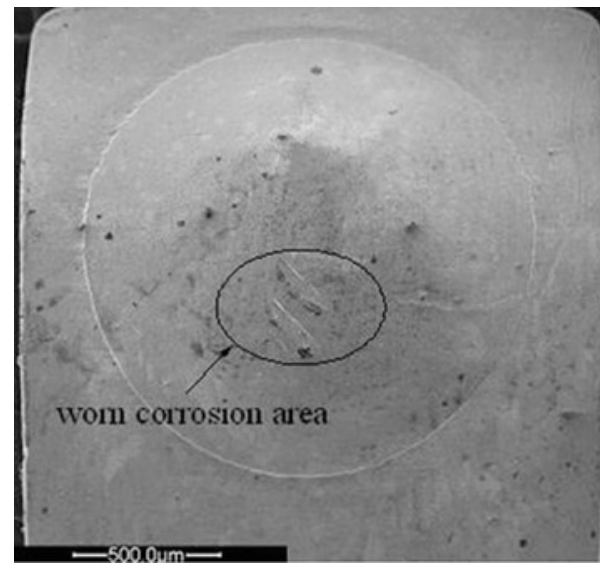

a) N.C.static contact

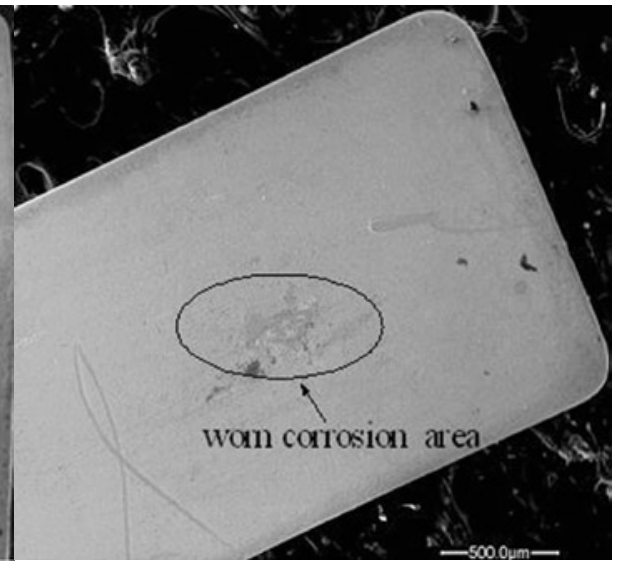

b) Movable contact

Fig. 13. The N.C.static contact SEM morphology of new relay sample

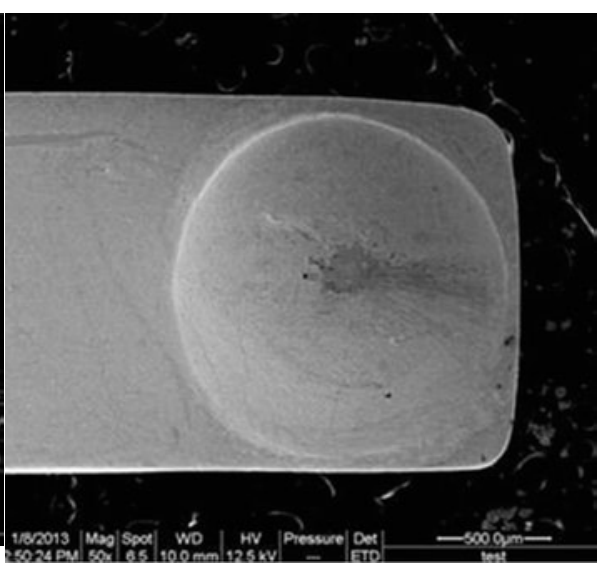

d) $170^{\circ} \mathrm{C}$ storage test condition

centers on the fray and from inside out, these oxidized corrosion is continuously covered annularly. From the phenomena above, we can see that the temperature has the effect to accelerate and boost the oxidized corrosion of the contacts during the process of the relay storage.

The temperature plays the role of promoting and accelerating contacts to degenerate during storage of aerospace relay. In order to further analyze the impact of storage time to the relay contacts degradation, the SEM morphology for each contact of specimen relay at four different temperature stress and different time were analysed. Here we use the storage test at $170^{\circ} \mathrm{C}$ temperature stress as example. Its degradation is more evident. Figure 15 a)-d) are relay sample static contact surface SEM morphology photos in the temperature stress 


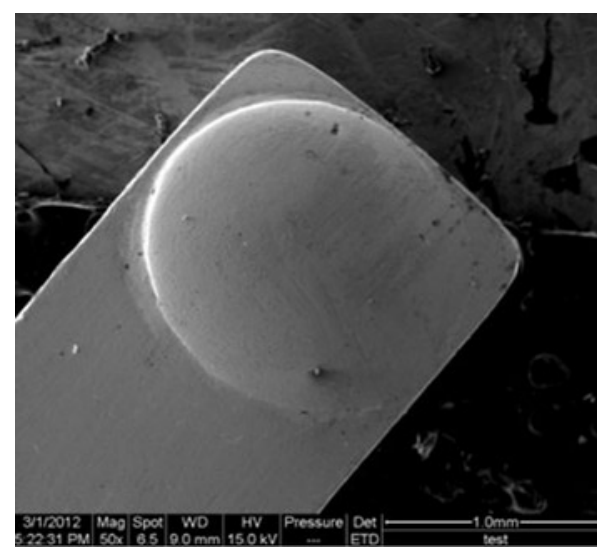

a) 3 months

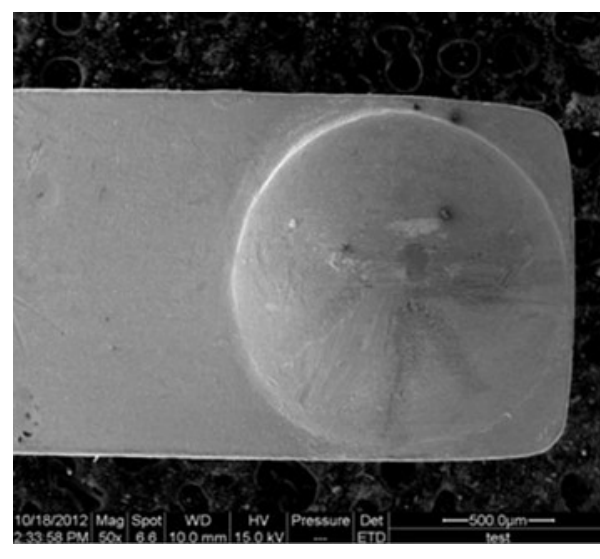

c) 10 months

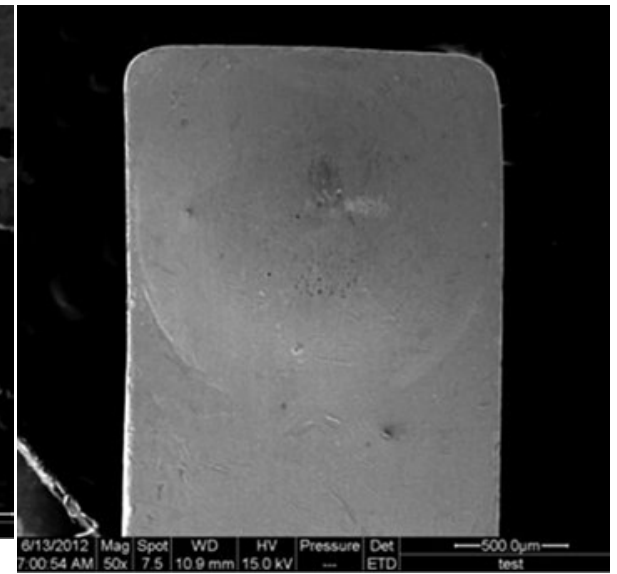

b) 6 months

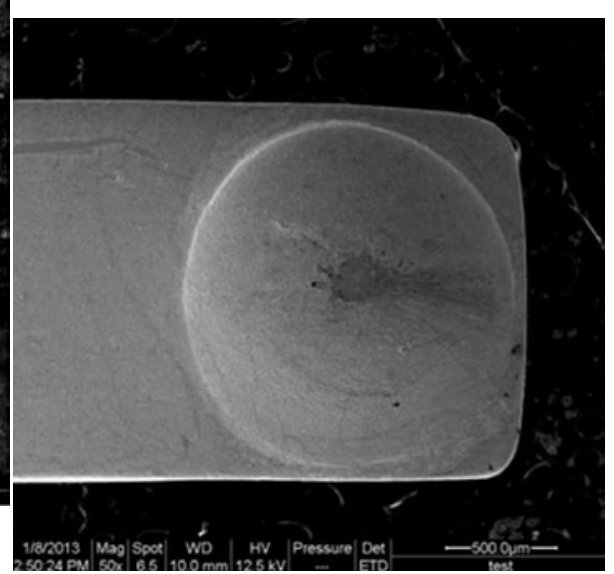

d) 12 months

gold $(\mathrm{Au})$ elements. Further we can quantitatively calculate that the mass and atomic number percentage of gold elements is almost $100 \%$. This is mainly because aerospace relay contact surfaces are required to be gold-plated, whose thickness is generally $1.8-3.2 \mu \mathrm{m}$, and the new test environment is not affected by the oxygen corrosion of environment stress oxygen and other corrosive elements. Therefore, there are no other pollution elements basically.

The 2000 $\times$ magnified SEM image of N.C. static contact surface after 12 months of storage test in $170^{\circ} \mathrm{C}$ is shown in Fig. 17 .

Through EDX scanning, gold $(\mathrm{Au})$ elements, silver $(\mathrm{Ag})$ elements, oxygen $(\mathrm{O})$ elemental sulfur (S) and other elements can be found in its contact surface. It can be inferred that as the storage time extends, sealing of relay decreased; atmospheric corrosive gases, moisture and micro-cracks through the coating. Infiltrate and contact with the microscopic silver substrate by capillary action, deposited into electrolyte. Potential difference exists between silver and gold, so that the primary battery is formed between the coating metal gold and silver substrate interface, which would cause an oxidation-reduction reaction. Because of strong chemical activity, diffusion velocity of $\mathrm{Ag}^{+}$in solid oxide is much greater than that of oxygen, so $\mathrm{Ag}^{+}$is easily diffused into the contact surface between oxide and gas, which is mean that diffusion rate of $\mathrm{Ag}$ in $\mathrm{Au}-\mathrm{Ag}$ interface is faster than that of $\mathrm{O}_{2}$. Besides when the air contains sulfur contaminants electrochemical reduction reaction occurs at the surface of the gold layer,

Fig. 15. The N.C.static contact SEM morphologys in $170^{\circ} \mathrm{C}$ with different time

for 3 months, 6 months, 10 months and 12 months. What we can see from the figure is that as the test time increases, the oxidized corrosion of contact is becoming more and more severely.

\subsubsection{EDX analysis of relay contacts}

The line scan and area scan analysis of EDX for contact samples were test. EDX is an important ancillary instrument for scanning electron microscopy. Combined with SEM, EXD can do the microscopic qualitative and quantitative measurement and analysis for chemical elements of microscopic contact area and its distribution.

Figure 16 is the result of new specimen static contact surface scanned by EDX. We can see that the surface has only one peak of

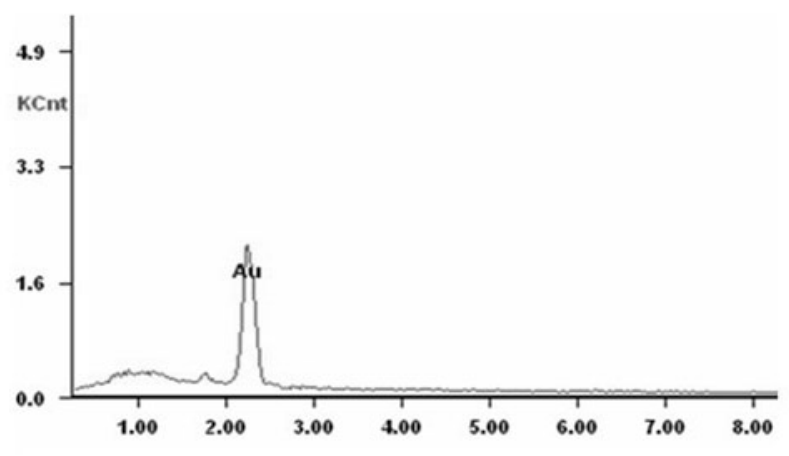

a)Energy dispersive $x$-ray spectrum

b) Chemical composition percentage

Fig. 16. EDX and chemical composition percentage of new-sample N.C. static contact time

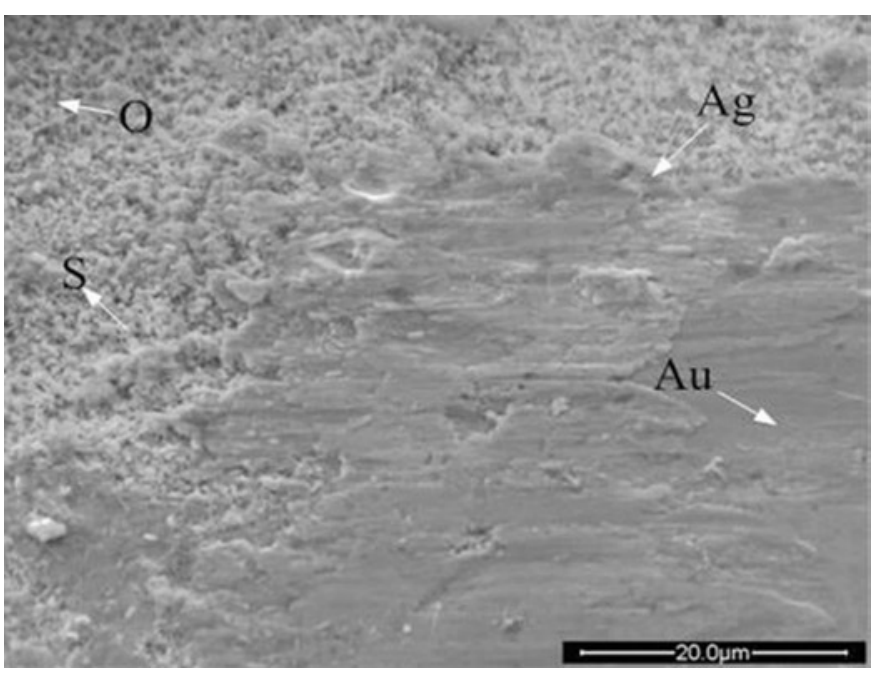

Fig. 17. 2000 $\times$ magnified SEM image of contact surface after test different

\begin{tabular}{|l|l|l|}
\hline Element & $\boldsymbol{W} \boldsymbol{t} \%$ & $\boldsymbol{A t} \%$ \\
\hline AuM & 100.00 & 100.00 \\
\hline \hline
\end{tabular}

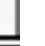
namely the contact surface and form dark
black film of silver sulfide and oxide which has high resistivity.

To further observe contact of base metal, metal plating and film thickness of corrosion etc, we could analyze section of contact by SEM and EDX .As is shown in figure 18, it 


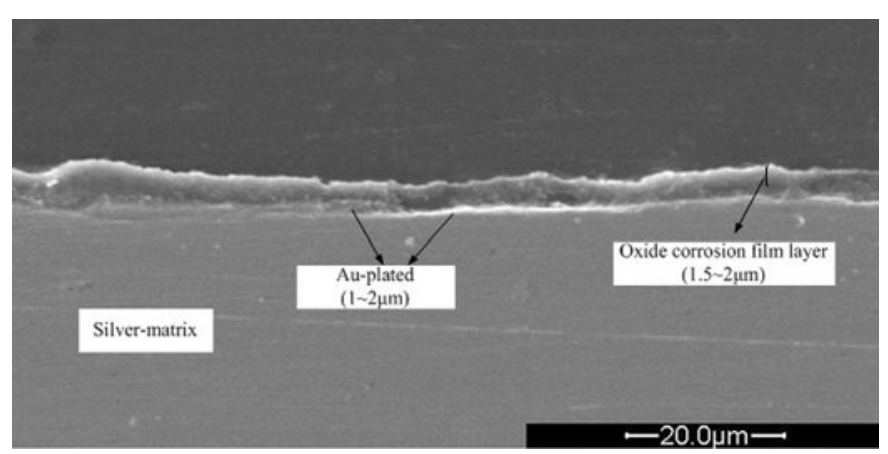

Fig. 18. SEM image of the cross section for the relay N.C. static contact

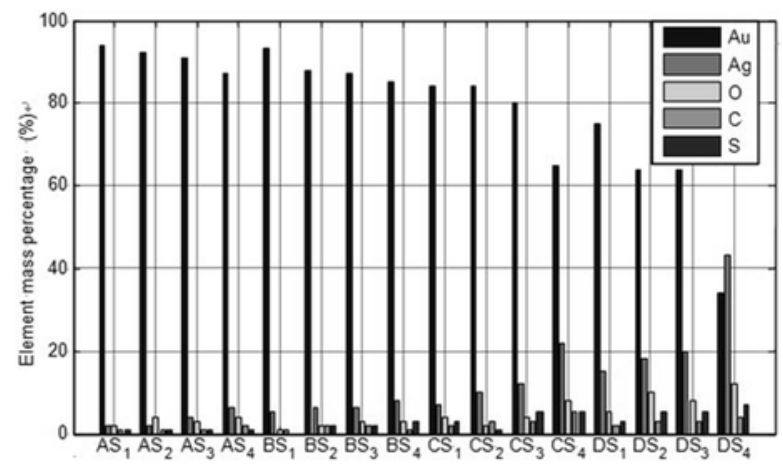

Fig. 19. The weight percentage of N.C. static contact elements of relay samples in storage test

is not difficult to see that after long storage, the surface of aerospace relay contact forms a high resistivity sulfide and oxide film, resulting in increasing of contact resistance, contact performance decline even eventually contact failure.

Figure 19 is the weight percentage of N.C. static contact elements of relay samples in storage test under different test time and stress with different temperatures.

In figure 19 , A represents the sample under $80^{\circ} \mathrm{C}$; B represents the sample under $106^{\circ} \mathrm{C}$; C represents the sample under $135^{\circ} \mathrm{C}$; D represents the sample under $170^{\circ} \mathrm{C}$ in the diagram. $\mathrm{S}_{1}$ represents 3 months storage time; $\mathrm{S}_{2}$ represents 6 months storage time; $\mathrm{S}_{3}$ represents 10 months storage time; $S_{4}$ represents 12 months storage time. The figure shows that with the extension of storage time, the surface of the contact emerges base metal silver (Ag) elements, and the proportion continues to grow. Furthermore, oxygen $(\mathrm{O})$ element, carbon $(\mathrm{C})$ element, sulfur (S) element and other elements appears; besides with the increase of test time and temperature stress the proportion of such element has increased differently.
It can be determined from analysis of SEM and EDX test that with the increasing extension of storage time and temperature stress, the contact surface forms a corrosion layer consisting with less conductive oxides, sulfides, and carbides, affecting gradually the contacts contact performance, and may eventually lead to contact failure of the relay contact. Above test results provides a basis and reference of improving storage reliability for relay manufacturers on the microlevel. The storage reliability can be improved by increasing the level of the relay tightness and improving contact spring manual assembly process, reducing personal contact mechanical friction. The analysis of SEM and EDX test provides a microscopic basis for the physics of failure modelling in aerospace EMR storage.

\section{Conclusion}

This investigation mainly aims to determine the degradation characteristics and failure mechanisms of aerospace electromagnetic relay in accelerated storage degradation testing. Our results indicate that when the temperature-accelerated stress is higher, the rate of contact resistance growth is faster, and the value is also greater. The trend of pick-up time values descend is obvious, and the value is also smaller. The relay contact resistance and pick-up time satisfy two characteristics described in determination degradation sensitive parameters.

The contact failure mechanism of aerospace EMR in long-term storage is investigated. From analysis of SEM and EDX test, the contact surface forms a corrosion layer consisting with less conductive oxides, sulfides, and carbides, affecting gradually the contacts contact performance, and may eventually lead to contact failure of the relay contact with the increasing extension of storage time and temperature stress. Above test results provides a basis and reference for latter aerospace EMR storage life and storage reliability improving.

\section{Acknowledgement}

The authors are grateful to the anonymous reviewers, and the editor, for their critical and constructive review of the manuscript. This study was co-supported by the National Natural Science Foundation of China (Grant No. 51507074), China Postdoctoral Science Foundation (Grant No. 2015M571898), the Natural Science Foundation of Higher Education Institutions of Jiangsu Province (Grant No. 15KJB470003), and the Open Foundation of Zhejiang Provincial Top Key Academic Discipline of Mechanical Engineering and Zhejiang Sci-Tech University Key Laboratory (Grant No. ZSTUME01A02).

\section{References}

1. Guo F Y, Chen Z H. Electrical Contacts Theory Applications and Technology, China Electric Power Press, Beijing, 2008.

2. Holm, R. Electrical Contacts . Springer-Verlag Berlin Heidelberg GmbH 1981

3. Książkiewicz A, Janiszewski J. Low voltage relay contact resistance change influence by short-circuit current. Eksploatacja i Niezawodnosc - Maintenance and Reliability 2015; 17 (4): 600-603, http://dx.doi.org/10.17531/ein.2015.4.16.

4. Li K, Lu J G, Zhang G S. The approach to predication of contact reliability for relay. Transactions of China Electrotechnical Society 1999 ; 14(2): 55-59.

5. Li L, Xu W. Optimum scheme design and analysis of accelerated life test for sealed electromag-netic relay. Low Voltage Apparatus 2010; (4): 13-16.

6. Lu J G, Jin F Q. Reliability design on electromagnetic system of relay. Proceedings of 36th Relay Conference 1988:1-4.

7. Luo Y Y, Lu J G. Li W H, Wang L Z. Study on the accelerated life test of storage life for sealed electromagnetic relays. Acta Armamentarii 2007; 28(8): 997-1001. 
8. Ma X B, Wang J Z, Zhao Y. Reliability assessment using constant-stress accelerated degradation data based on pseudo life distribution. Journal of Systems Engineering and Electronics 2011; 33(1): 228-0232.

9. Mcpherson J W. Reliability Physics and Engineering, New York: Springer, 2010, https://doi.org/10.1007/978-1-4419-6348-2.

10. Meeker W Q, Hamada M. Statistical tools for the rapid development and evaluation of high-reliability products. IEEE Transactions on Reliability 1995; 44: 187-198, https://doi.org/10.1109/24.387370.

11. Meeker W Q, Escobar L A, Lu C J. Accelerated degradation tests: Modeling and analysis. Technometrics 1998; 40(2): 89-99.5.

12. Nelson W. Accelerated Testing: Statistical Methods, Test Plans, and data Analysis. New York: John Wiley Press, 1990, https://doi. org/10.1002/9780470316795.

13. Ren W B , Chen Y, Wang Z B, Zhang C and Zhai G F. Investigation of the $\mu$ N level adhesion force characteristics of gold-coated materials in air. The Journal of Adhesion 2016: 1-16, https://doi.org/10.1080/00218464.2016.1197125.

14. Ren W B, Chen Y, Wang Z B, Xue S J and Zhang X. Electrical contact resistance of coated spherical contacts. IEEE Transactions on Electron Devices 2016; 63(11): 4373-4379, https://doi.org/10.1109/TED.2016.2612545.

15. V N Nair. Discussion of estimation of reliability in field-performance studie. Technometrics 1988; 30(4): 379-383, https://doi. org/10.2307/1269798.

16. Wan B, Fu G C, Li N, Zhao Y H, Wang L. Storage life prediction of electromagnetic relay based on pof analysis. Annual Reliability and Maintainability Symposium 2013: 875-880, https://doi.org/10.1109/RAMS.2013.6517671.

17. Wang Y, Zhang C, Chen X, Tan Y. Lifetime prediction method for electron multiplier based on accelerated degradation test. Eksploatacja i Niezawodnosc - Maintenance and Reliability 2014, 16 (3): 484-490.

18. Zang C Y, He J J, Li J, et al. Contact resistance and surface film of sealed relay contacts . Proceedings of the CSEE 2008; 28(31): 125-130.

19. Zhai G F, Liang H M, Wang H, et al. Research on the parameters optimum design of polarized magnetic system based on orthogonal design. Proceedings of the CSEE 2003; 23(10): 157-163.

20. Zhai G F, Wang Q Y, Yang W Y. Permanent-magnet equivalent model of y,calculating relay's static attractive torque characteristics by finite element method, IEEE Transactions on Magnetics 2012; 48(9): 2467-2471, https://doi.org/10.1109/TMAG.2012.2196705.

21. Zhang J. H., Kong X B.The failure mode analysis of low frequency electrical connectors. Electromechanical Components 1989; 9: 36-43.

\section{ZhaoBin WANG}

School of Electronics and Information Jiangsu University of Science and Technology

No.02 Mengxi Street, Jingkou District

Zhenjiang, Jiangsu, 212003, P.R. China.

Post-doctoral research center, School of Mechanical Engineering and Automation

Zhejiang Sci-Tech University

No.928 Second Avenue, Xiasha Higher Education Zone

Hangzhou, Zhejiang, 310018, P.R. China

\section{Shang SHANG \\ JiaWei WANG \\ ZhouLin HUANG \\ Fu SAI}

School of Electronics and Information Jiangsu University of Science and Technology

No.02 Mengxi Street, Jingkou District

Zhenjiang, Jiangsu, 212003, P.R. China.

E-mail:wangzb@just.edu.cn, shangshang@just.edu.cn, majestyW@126.com, 1535717833qq.com, fusai2015@163.com 